\title{
Toilet: Dari Mohenjodaro hingga DPR
}

\author{
Oleh Fathurozi \\ Pengaji Budaya di Pancur Studies, Staf Balai Penelitian dan \\ Pengembangan Agama, Semarang
}

Toilet atau kloset (closed) memang bukan tempat utama dari sebuah rumah, perkantoran, atau bangunan lainnya. Namun, betapapun minor atau terkucilkan, toilet memiliki fungsi yang vital dan tak tergantikan.

Dalam hidup manusia, secara sosial dan personal, toilet ternyata bukan sekadar tempat kita membuang hajat, tetapi juga menjadi pelepas stres, tempat merenungkan persoalan, membaca, bahkan untuk mendapatkan inspirasi. Betapapun ia disembunyikan, toilet ternyata adalah bagian tak terpisahkan dari hidup kita, manusia.

Karena itulah, satu-satunya bagian dari rumah kita yang selalu ada di semua tempat keramaian, pasar, mal, kantor, SPBU, dan sebagainya adalah toilet. Seolah-olah kita pergi dan berkegiatan dengan membawa toilet ke mana saja.

Konon terciptanya kloset sekitar tahun 3000-1500 SM di ibu kota Hindustan, Mohenjodaro. Dengan hilangnya peradaban Hindustan, kloset pun ikut sirna. Sekitar tahun 1596, Sir John Harington memproduksi dua kloset dan diberi nama "ajak", salah satu klosetnya dipakai Ratu Elizabeth I. Tak ayal Harington dijuluki sebagai Bapak WC (Water Closed).

Tahun 1775 Alexander Cummings menemukan kloset bilas yang tidak bau (valve closet). Lalu, ia pun mendaftarkan hak patennya. Setelah Cummings menemukan kloset siram, kemudian Joseph Bramah seorang tukang kunci juga menemukan kloset yang diberi engsel pada penutupnya. Ketiga tokoh tersebut saling melengkapi sehingga tercipta kloset yang nyaman bagi penggunanya.

Seiring perkembangan zaman, bentuk toilet dimodifikasi. Ada toilet yang menyerupai kepala manusia, perempuan menghadap ke belakang, dan simbol lidah dari band papan atas yang terkenal di dunia hiburan.

\section{Toilet di kita}

Dahulu masyarakat Indonesia melakukan ritual mandi, cuci baju atau peralatan dapur, bahkan bahan masakan hingga membuang hajat di tempat yang sama: sungai. Kita belum mengenal semua fungsi di atas dalam satu ruang yang khusus. Kegiatan membuang hajat masih dianggap sebagai aktivitas kolektif, seperti mandi dan mencuci.

Dalam buku berjudul Cleanliness and Cultural Indonesian Histories karya Kees Van Dijk (2011), pemerintah kolonial Belanda memperkenalkan kloset kepada masyarakat Indonesia, tetapi masyarakat pribumi kurang bisa menerima kehadiran kloset karena tak percaya kemampuan kloset yang berlubang kecil mampu menampung semua isi perut manusia.

Menurut Van Dijk lagi, pemerintah kolonial Belanda kemudian mengintroduksi pemahaman rumah dengan klasifikasi ruang yang lebih kompleks. Dibedakan ruang publik dan ruang privat semisal kamar mandi, kamar tidur, atau ruang dapur. Pembagian tidak untuk menciptakan sekat interaksi warga, tetapi untuk menciptakan kebersihan. Sejak itu peradaban higienis Indonesia dimulai. 
Namun, masyarakat Indonesia itu ternyata kurang bisa menerapkannya. Seperti yang ditulis harian Kompas, "Wangi di Depan, Jorok di Belakang" (25/3/2012), dikisahkan seorang wanita yang bekerja di lembaga pemerintahan membuang hajat di toilet. Setelah buang hajat, dia tidak menyiramkan air. Kebiasaan ini biasa dilakukan laki-laki maupun perempuan.

Tetapi, belakangan sikap dan perilaku masyarakat kita terhadap kloset atau toilet tampak sudah mulai berubah.

\section{Toilet DPR}

Perubahan itu tentu belum menyeluruh. Masih banyak anak-anak yang merasa takut untuk ke toilet malam hari karena dihantui spekulasi mistis tertentu. Entah dengan alasan apa bila kemudian DPR ngotot untuk memperbaiki toilet, bahkan dengan biaya miliaran rupiah. Apakah ada hajat lain yang dibuang di situ? Siapa yang tahu?

Khusus bagi sastrawan, kloset sungguh memberi bukti melahirkan inspirasi, bahkan tentang kloset atau toilet itu sendiri. Semisal cerpen yang berjudul Malaikat Kakus karya Triyanto Triwikromo (2005), juga cerpen Coret-coret Toilet (2001) karya Eka Kurniawan, atau Radhar Panca Dahana dalam puisinya, Toiletku (2008). Ada juga Toilet Kalau Vampir Kebelet Gaul karya Endang Rukmana 2009) dan kumpulan puisi Renungan Kloset: Dari Cengkeh Sampai Utrecht (2003) karya Rieke Diah Pitaloka.

Sebuah buku karya Michael Szymczyk, Toilet: The Novel (2004), mengisahkan seorang pria gila akibat perang nuklir. Dalam kebimbangannya, orang tersebut lari ke toilet untuk mencari solusi.

Atau bahkan toilet milik JD Salinger, pengarang novel The Catcher in The Rye dari Amerika Serikat, dalam situs lelang online eBay, dilelang dan mendapatkan harga 644,000 (enam miliar rupiah lebih). Entah kenapa, mungkin karena Salinger diketahui telah menulis 15 naskah terbaiknya dari ilham dan perenungan di dalam toilet.

Seorang teman yang berprofesi sebagai desain grafis di Kota Semarang pernah mengatakan, ketika sedang melakukan pekerjaan, lalu di tengah-tengah ide kreatifnya mandek, ia selalu lari ke kamar mandi untuk mencari ide. Bagi dia, toiletlah yang telah membantu melahirkan karya-karya kreatifnya.

Di sisi lain, toilet dijadikan ruang ekspresi bagi sebagian orang. Kita bisa lihat foto-foto berlatar ruang toilet di jejaring sosial Facebook dan Twitter. Bahkan terdapat restoran berdekorasi serba toilet, bukan hanya di satu negara, melainkan sekaligus di China, Jepang, dan Taiwan.

Adakah toilet semacam itu dalam hidup Anda? Mungkin tidak selalu di dalam rumah atau kantor Anda. Jangan-jangan makna yang sama ada dalam pikiran dan hati Anda. Siapa yang tahu?

Di muat Kompas 17 November 2012 